This work is licensed under a Creative Commons Attribution 4.0 International License.

Ovaj rad dostupan je za upotrebu pod licencom Creative Commons Imenovanje 4.0 međunarodna.

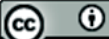

Milijana MIČUNOVIĆ

UDK 1:004

Filozofski fakultet

378:316.7

Sveučilišta J. J. Strossmayera u Osijeku

DOI: https://doi.org/10.29162/ANAFORA.v7i2.5

Lorenza Jägera 9

HR - 31000 Osijek

Pregledni članak

mmicunov@ffos.hr

Review Article

Boris BOSANČIĆ

Filozofski fakultet

Sveučilišta J. J. Strossmayera u Osijeku

Lorenza Jägera 9

HR - 31000 Osijek

bbosancic@ffos.hr
Primljeno 25. rujna 2020.

Received: 25 September 2020

Prihvaćeno 20. prosinca 2020.

Accepted: 20 December 2020

\title{
HUMANISTIKA IZ PERSPEKTIVE TRANSHUMANIZMA I POSTHUMANIZMA
}

\section{Sažetak}

Transhumanizam je intelektualni, kulturni, znanstveni i umjetnički pokret koji, temeljen na sprezi znanosti, tehnologije i gospodarstva, podržava i potiče razvoj i uporabu novih znanstvenih i tehnoloških rješenja za poboljšanje ljudskih fizičkih, mentalnih i drugih sposobnosti. S druge strane, posthumanizam predstavlja termin koji se ponajviše veže uz redefiniranje pojma ljudskog, odnosno humanog u skladu s ontoepistemološkim, znanstvenim i biotehnološkim razvojem s kraja dvadesetog i početka dvadeset i prvog stoljeća. Neminovno se preklapajući, ta dva pokreta ili pravca mišljenja neumitno utječu i na razvoj humanistike koju u današnje vrijeme obilježava tzv. tiha kriza koja se očituje u zanemarivanju ne samo umjetnosti i humanističkih znanosti, već i imaginacije, kreativnosti i kritičkog mišljenja u svakom znanstvenom području. O budućnosti humanističkih znanosti iz perspektive transhumanizma i njegova sustava vrijednosti moguće je izdvojiti dva glavna uvida ili poveznice. Prvi se tiče pozicioniranja humanistike, odnosno njezina odnosa spram prirodnih i tehničkih znanosti, dok se drugi tiče pitanja vrijednosti i vještina koje humanističke znanosti žele promicati, posebno u odnosu na izazove koje donosi znanstveno-tehnološka revolucija. Iz posthumanističke perspektive pak predlaže se 
potpuna rekonfiguracija humanističkih znanosti koja bi dovela do toga da se čovjek ukloni iz središta humanističkih istraživanja. Stoga, humanistika mora mutirati u posthumanistiku, ultrahumanistiku i metahumanistiku, ako ne želi (p)ostati irelevantna i po strani razvoja i kretanja u suvremenom društvu. Kritička posthumanistika, u skladu s tim, predstavlja interdisciplinarno područje usmjereno na nove diskurse u području nehumanog, transhumanog, metahumanog i posthumanog, odnosno na različite percepcije fenomena 'humanog', a posljedično i percepcije humanistike u posthumanom dobu.

Ključne riječi: humanističke znanosti, transhumanizam, posthumanizam, posthumanistika

\section{Uvod}

Kriza humanistike podrazumijeva ono što Martha Nussbaum naziva tzv. tihom krizom (engl. silent crisis) - zanemarivanje ne samo umjetnosti i humanističkih znanosti, već i imaginacije, kreativnosti i kritičkog mišljenja kao ključnih odlika svakog znanstvenog područja. Ta je kriza, posebice vidljiva u suvremenom društvu inspiriranom i usmjeravanom STEM područjima, transhumanizmom, posthumanizmom i drugim tehnoznanstvenim obećanjima 'konačnog' ostvarenja čovjeka i njegova mikro- i makrokozmosa. Neke od najeminentnijih odlika transhumanističke i posthumanističke misli - tehnologizacija, komodifikacija, utilitarizam, algoritimizacija, sekularnost, zakoni tržišta i potrošačkog individualizma - prodiru u gotovo sva područja čovjekova djelovanja, pa tako i u područje obrazovanja i znanosti. Pragmatizacija informacija i znanja, libertarijanizacija i deinstitucionalizacija obrazovnog sustava, kao i objektiviziranje aktera/entiteta uključenih u obrazovni proces polako narušavaju njegovu dosadašnju homeostazu uzrokujući transformaciju humanistike u posthumanistiku, emergentno područje utemeljeno na konvergenciji posthumanizma i postantropocentrizma.

U radu se najprije daje osvrt na transhumanizam kao pokret, te izlažu njegove pretpostavke, a zatim i razmatra položaj humanistike u kontekstu transhumanističkih vrijednosti. Posebna pozornost posvećuje se pitanju je li moguć opstanak humanistike iz transhumanističke perspektive. U drugom dijelu rada izlažu se i pretpostavke posthumanizma s ontoepistemološkog stajališta te ocrtava mogući razvojni put posthumanistike koji se temelji na rekonfiguraciji humanističkih znanosti u cjelini. 


\section{Transhumanizam i njegove pretpostavke}

„U početku je stvoren Svemir. To je mnoge jako razljutilo i danas naširoko vrijedi tvrdnja kako je to bila loša zamisao."

(Douglas Adams, Vodič kroz galaksiju za autostopere)

Kulturni i filozofijski začeci transhumanizma vežu se uz brojna kulturna, umjetnička i filozofska ostvarenja ljudske misli i duha. Svima im je zajedničko promišljanje o ljudskoj prirodi, o položaju čovjeka u univerzumu, o važnosti spoznaje i znanja te o pitanjima ovladavanja prirodom. Termin „transhumanizam“ spominje se sredinom 20. stoljeća pa je tako Julian Huxley prve transhumanističke ideje, odnosno termin „transhumanizam“ popularizirao još 1957. godine. Njegov je transhumanizam antropocentričan i naglašava jedinstvenost i posebnost ljudske prirode. Kasnije, tijekom 90-ih godina prošlog stoljeća, filozof i futurist Max More predstavlja definiciju transhumanizma kao tzv. posthumanog stanja koje predstavlja nužno i moralno dobro čovječanstvu (Bostrom 1-4; Ferrando i Braidotti 29-30).

Transhumanizam se najčešće definira kao intelektualni, kulturni, znanstveni i umjetnički pokret koji, temeljen na sprezi znanosti, tehnologije i gospodarstva, podržava i potiče razvoj i uporabu novih znanstvenih i tehnoloških rješenja za poboljšanje ljudskih fizičkih, mentalnih i drugih sposobnosti, za unaprjeđenje prirodnih vještina, ali i za poništenje svih onih nepoželjnih i nepotrebnih aspekata ljudskog stanja, poput gluposti, patnje, bolesti, starosti i smrti. Sam pojam „poboljšanje“ čest je uzrok rasprava budući da pretpostavlja moralnu dužnost - zašto ne odabrati ono što je dobro i 'poboljšano'. Prema mišljenju Jotteranda (617) i Hughesa (622) radi se o ideologiji ukorijenjenoj u prosvjetiteljstvu, odnosno ideologiji koja je dijelom tzv. prosvjetiteljske filozofije. Mnogi pripadnici transhumanizma smatraju ga svojevrsnim proširenjem humanizma ili ultrahumanizmom koji je 'nadrastao' sekularni humanizam i prosvjetiteljstvo. Poput humanista, transhumanisti vjeruju u razum, napredak i vrijednosti koje u svojim temeljima podrazumijevaju dobrobit čovjeka, a ne u nekakav 'vanjski' (religijski) autoritet. No, kao pokret i filozofija transhumanizam nije homogen, pa se tako razlikuju četiri vrste transhumanizma - demokratski transhumanizam, liberalni transhumanizam, ekstropijanizam i singularitet (Ferrando).

Posljednjih je godina izraženije političko djelovanje nekoliko transhumanističkih političkih stranaka čiji je cilj osvijestiti pitanje promjenjivog odnosa 
između čovjeka i tehnologije kao temeljnog čimbenika budućih društveno-političkih procesa te upozoriti na nužnost smanjenja utjecaja države i njezine administracije, kao i na transformaciju tržišta rada (Benedikter i Siepmann 1-10). Tako se uz temu transhumanizma sve češće vežu i brojna druga pitanja, poput onih iz socioekonomske sfere - problem masivne nezaposlenosti, pitanje osnovnog temeljnog dohotka, ${ }^{1}$ kao i pitanje obrazovnih politika (npr. biotehnologija i infotehnologija koje su temelj transhumanističke transformacije čovjeka i društva, ujedno su i temelj STEM revolucije). Iako već svojim temeljnim pretpostavkama i idejama otvara brojne rasprave izazivajući stavove, mišljenja i emocije i znanstvene zajednice i javnosti, transhumanizam, sada već i kao društvena paradigma, počinje ispoljavati sve očigledniji društveni i politički utjecaj na širu socioekonomsku sferu ... što se mnogima može činiti kao loša zamisao.

\section{Humanistika u kontekstu transhumanističkih vrijednosti}

„Osjećam da se bliži kraj svijeta. Ljudi su izgubili povjerenje u sebe.“

(Hayao Miyazaki u dokumentarnom filmu Never-Ending Man: Hayao Miyazaki³)

Dok se kršćansko društvo vodilo principima i vrijednostima duha, a humanističko principima morala i razuma, tehnološki ovisno postmoderno društvo vođeno je principima mehanicizma, redukcionizma i ne-krajnosti (u smislu nepostojanja konačne granice razvoja i napretka) koji u simbiotskom odnosu s konzumerizmom tvore čisto materijalističku i objektivističku paradigmu. I premda, upravo zahvaljujući mogućnostima moderne tehnologije, danas postoji mnogo prilika za eskapizam od sve zamornijeg realiteta, u konačnici ne postoji stvarna mogućnost odustajanja ili isključenja (engl. opt-out). Politička ekonomija naprednog kapitalizma (Braidotti 34) i tehnoznanstveni determinizam oblikuju moderne društveno-ekonomske silnice koje djeluju disruptivno na gotovo sve aspekte suvremenog života, od pitanja politike identiteta i prirode međuljudskih odnosa do vrlo egzaktnih pitanja, kao što su gospodarska politika i promjene na tržištu rada. Entropija i kaos s kojima se suočavamo jednako se tako manifestiraju i u području znanosti i obrazovanja. Kontinuitet je prestao

\footnotetext{
${ }^{1}$ Universal basic income ili Basic Guaranteed Income.

${ }^{2}$ I feel the world's end is near. Humans have lost confidence.

${ }^{3}$ Dokumentarni film iz 2016. godine posvećen Miyazakijevu liku i djelu koji prati njegov profesionalni put od najave umirovljenja 2013. godine pa nadalje.
} 
biti definirajućom odrednicom modernog doba, dok problematika raslojavanja, nepredvidivosti i relativizma, uz diskurzivnu, zauzima sve više i empirijsku pojavnost. Tim postmodernim pomacima u područje nesigurnosti, utilitarnih mjerila i opće oportunističke instrumentalizacije pridružuju se nove znanstveno-tehnološko-medijske maksime te zajedno stvaraju okoliš neprestane sumnje i propitivanja. U takvom se okolišu promijenila ne samo društvena i politička percepcija humanističkih znanosti, nego i njihova samopercepcija.

U knjizi Digitalni odrast i postdigitalna dobra: kritičko bibliotekarstvo, disruptivni mediji i taktičko obrazovanje Hibert upozorava na nekoliko trendova koji predstavljaju ozbiljne izazove za društvo znanja i javnu sferu. Većina se spomenutih trendova može staviti u (ne)posrednu vezu i s krizom humanistike. Hibert tako spominje političko-ekonomsku aktualizaciju tehnologije i ideološko povezivanje vlade, poslovnog (poduzetničkog) sektora i akademske zajednice što se ponajbolje ogleda u aktualizaciji STEM revolucije, porastu popularnosti studija u području tehničkih i prirodnih znanosti te trendu formiranja interesnih znanstvenih zajednica oko projektnih ideja i prijedloga ${ }^{4}$. Prodor komodifikacijske logike u sve sektore i institucije i opća komercijalizacija i kvantifikacija koje je Hibert, također, izdvojio, možda su najeklatantniji uzroci krize humanističkih znanosti jer kao rezultat znanstvenog rada predmnijevaju 'proizvod' koji će u očima javnosti, države, ali i institucijskih kolega, financijski i ekonomski opravdati njihovo postojanje. Tu su i trendovi fetišizacije informacija, datafikacije kao izvora spoznaje, i algoritmizacije, tj. industrijalizacije i automatizacije ljudskog uma i procesa mišljenja koji neposredno utječu na oblikovanje kurikula i prirodu i proces učenja i poučavanja. Navedenim bi se trendovima mogli pridružiti i sve prisutnija birokratizacija (koja traži sve višu razinu birokreativnosti), ali i drugi aspekti tehnosfere: (neo)liberalizam i tržišna politika, tehnologizacija, komodifikacija, objektiviziranje, sekularnost, deinstitucionalizacija, pragmatizacija i ukalupljivanje. ${ }^{5}$

Što se u tom kontekstu događa s institucijom sveučilišta? Lyotard ocrtava poprilično pesimističnu sliku sveučilišta smatrajući da se ono sve više oprav-

\footnotetext{
${ }^{4}$ Fenomen koji u svojoj 'opasnijoj' varijanti pretpostavlja 'projektno usmjeravanje znanosti', odnosno prilagodbu znanstvene ideje i teorije opisu ciljeva projekta, tj. uvjeta za prijavu projektnih prijedloga, kao i transformaciju profesora/znanstvenika u projektnog menadžera.

${ }^{5}$ Pravilo ukalupljivanja, prema mišljenju Heideggera i Fukuyame, proizlazi iz pravila tehnike i tehnologije te predstavlja jednu od ozbiljnijih ugroza čovjekove prave prirode i njegove kreativnosti postupno mijenjajući njegovu bit.
} 
dava načelima korisnosti i performativnosti, a sve manje načelima dostojanstva i slobode (49). Uslijed toga, sveučilište kao institucija visokog obrazovanja sve se više potčinjava interesima vlasti i tržišta, pri čemu odgovornost prijenosa znanja više nije isključivo na znanstvenicima i studentima (74). Marcelić (41-58), također, ističe dominaciju praktične i komercijalne dimenzije visokog obrazovanja potaknute prodorom neoliberalnih javnih politika u domenu obrazovanja i znanosti što, posljedično, uzrokuje marginalizaciju humanističkih i društvenih znanosti u odnosu na prirodne i tehničke znanosti te stvaranje tzv. poduzetničkog sveučilišta, tj. akademskog kapitalizma. Zbog svega navedenog, humanističke znanosti svoje opravdanje moraju steći ulaskom u domenu znanstvenih projekata, stvaranjem primarno primjenjivog i ekonomiziranog znanja koje će ojačati njihovu percepciju kao performativnih i ekonomski isplativih znanosti te tržišnim pozicioniranjem upućivanjem na socijalno poduzetništvo. Iako su načela inovativnosti i primjenjivosti važni pokretači znanosti, Marcelić upozorava da preveliko inzistiranje na inovacijama i patentima, primjenjivosti i transferu tehnologija dovodi do zanemarivanja teorijskog potencijala znanosti.

Pitanjem krize same humanistike konkretnije se bavila Martha C. Nussbaum u svojoj knjizi Ne profitu: zašto demokracija treba humanistiku. I Nussbaum zaključuje da je krizu humanističkih znanosti potrebno staviti u kontekst širih globalnih političkih i gospodarskih prilika kao što su orijentiranost na financijski i gospodarski rast, birokratizacija, tržišna kompetitivnost, i dr. No, Nussbaum ne pokušava pronaći 'opravdanje’ za humanističke znanosti i obrazovanje, već, isticanjem njihovih vrijednosti, omogućiti modernom društvu da ih prepozna kao ključnu kariku moderniteta, tj. Postmoderniteta. Vrijednost humanističkog obrazovanja očituje se u njegovu promicanju i čuvanju demokratskih institucija i demokratskih vrijednosti. Za suvremenu je demokraciju nužno njegovati i sačuvati humanističko nasljeđe, posebice u obliku razvoja kritičkog mišljenja i kritičke rasprave i argumentiranja, razvoja (narativne) imaginacije, kreativnosti i suosjećanja s drugima, kao i razvoja građanske kulture i zajedništva koje će omogućiti globalni pristup problemima modernog društva. Upravo su to vještine kojima humanističke znanosti trebaju buduće generacije pripremiti za njihovu profesionalnu i privatnu budućnost.

Bolecki pak specifičnost problematike humanističkih znanosti vidi u njihovoj ontološkoj, kognitivnoj i funkcionalnoj razlici u odnosu na druge znanosti (47-52). Pritom izdvaja nekoliko 'problemskih mjesta' koja upućuju na krizu humanistike - stalni pokušaj definiranja humanističkih znanosti u odnosu na 
egzaktne i eksperimentalne znanosti, pokušaj nehumanističkih znanosti da zauzmu mjesto humanističkih znanosti, nedovoljno financiranje humanističkih znanosti i pitanje njihova (re)pozicioniranja unutar visokoškolskog sustava, ali i njihovu vlastitu monolitsku percepciju uvijek istog 'vanjskog neprijatelja' (koji dolazi u oblicima poput kulturne infantilizacije i komercijalizacije, slabljenja obrazovanja i dr.). Ako žele revitalizirati svoje mjesto unutar sveučilišta i društva općenito, humanističke znanosti prije svega moraju, smatra Bolecki, pronaći novi model istraživanja, i interdisciplinarno i unutardisciplinarno (52).

U odnosu na Boleckog, Markowski smatra da problematika humanističkih znanosti ne izvire iz njihova određenja spram prirodnih i tehničkih znanosti, već u pitanju njihove opravdanosti i legitimnosti izvan i unutar sveučilišta, posebno ako se u obzir uzmu odluke država i privatnih institucija da smanje njihovo financiranje (14-24). Jer, sasvim je razumljivo da u društvu čiji su interesi usmjereni na ostvarivanje profita, postaje teže opravdati postojanje nečega što nije 'profitabilno' (ako nije profitabilno, onda ne služi interesima društva pa time ne može ni očekivati njegovu podršku). Unatoč tomu, humanističke znanosti ne bi se trebale braniti na način da ulaze u besmislene rasprave u javnom političkom prostoru, ili da se ponizno 'povlače na svoje mjesto' bivajući zahvalnima što im je dopušteno biti tu gdje jesu, ni očekivati da će se političari odjednom senzibilizirati za probleme humanistike. Jednako tako, dekani i uprava ne bi se trebali koristiti jezikom i diskursom neoliberalne ekonomije kako bi opravdali rezanje troškova, kao što se ni profesori ne bi trebali koristiti jezikom i diskursom svojih kritičara te svaku kritiku njihova rada percipirati kao osobni napad, odnosno napad na njihovo znanstveno područje i rad. Poput Nussbaum, i Markowski podržava konstruktivniji pristup koji dokida dualističku podjelu humanističkih znanosti i 'onih drugih', kao i percepciju humanistike kao one koja negira znanost, tehnologiju i kapital kao vrijedne i neizostavne pokretače civilizacijskih promjena i pomaka. Njegovo je mišljenje da humanističke znanosti ne opovrgavaju modernizaciju i znanstveno-tehnološki napredak, već kompenziraju sve 'praznine' i 'nedostatke' koji su nastali kao posljedica znanstvenog pogleda na svijet (15). Također, baš kao i Nussbaum, vjeruje da je misija humanističkih znanosti podržati raznolikost gledišta i mišljenja, te osim klasičnog prijenosa znanja, kod studenata pobuditi sumnju, maštu i (su)osjećajnost. Na kraju, humanističke znanosti imaju i političku moć koja ne smije upasti u zamku favoriziranja određenog oblika društvene imaginacije, već ukazivati na relativnost stvari koja ni jednoj ideologiji, viđenju ili skupu simboličkih reprezentacija ne 
daje pravo prvenstva. Ta moć možda nije tako egzaktna kao kod drugih znanosti, no njihovom sposobnosti da preoblikuju proces društvene imaginacije, humanističke znanosti mogu utjecati na način kako čovjek razmišlja o svijetu, kako ga promatra, otkriva i tumači, pa onda i kako djeluje u tom svijetu.

Postoji i pomalo distopijska ${ }^{6}$ percepcija budućnosti humanistike. Autori poput Gibsona (2-3) smatraju da će se humanistika, kako tehnologija bude sve više 'poboljšavala' čovjeka, morati transformirati u metahumanistiku u sklopu koje će profesor postati mentor i 'trener' čija je uloga njegovati studentov akademski i osobni potencijal, kurikuli i predmeti polako će nestajati, vrijeme će se sve više posvećivati razvoju inovacija, a naglasak će biti na cjeloživotnom učenju. Na kraju, sve će navedeno promijeniti ulogu i svrhu znanja. „Postaje jedino važno imati znanje/moć za transfiguraciju svijeta u formi biopolitičkoga objekta/stvari“ (Paić, Pitanje o prosvjetiteljstvu: Foucault i kritika modernosti 210). U tom se kontekstu pitanje dualizma između prirodnih i tehničkih znanosti i humanističkih znanosti više ne čini ključnim, niti je održivo, smatra Paić (Posthumano stanje: Kraj čovjeka i mogućnosti druge povijesti 36-42). Sada je nužno osvijestiti prirodu tehnologije koja nije neutralna i koja radikalno mijenja i predmet i subjekt istraživanja.

O stalnosti promjene u području znanja i znanosti najbolje svjedoče povijesne promjene obrazovnih paradigmi i određenja (definicija) znanja. Tako je, primjerice, u srednjovjekovnoj Europi formula za znanje glasila Znanje = Sveti spisi x Logika. Znanstvena je revolucija, potom predložila novu formulu - Znanje = Empirijski podatci $\mathrm{x}$ Matematika (Harari, Homo Deus: A Brief History of Tomorrow 192). Neovisno o pitanju prirode matematike kao nove bezvremenske konstante, znanstvena je revolucija dovela do brojnih novih saznanja u području mnogih znanstvenih disciplina. Međutim, novim problemom postaju pitanja vrijednosti i smisla; pitanja na koja su srednjovjekovni učenjaci mogli sa sigurnošću odgovoriti zato što „tako kažu sveti spisi”. Ni jedan set matematičkih podataka ne može dokazati da je umorstvo loš čin, a opet, čovječanstvo ne bi preživjelo bez određenih sustava vrijednosti. $U$ tom povijesnom trenutku nastupa humanizam i predstavlja alternativu, tj. novu formulu za etičko znanje - Znanje = Iskustvo x Osjećaji. Znanje stječemo tijekom godina iskustva $\mathrm{i}$ uz pomoć 'izoštrenih' osjećaja koji nam pomažu pravilno razumjeti nakupljena iskustva. Tako najvišim ciljem humanizma postaje dostizanje savršenog znanja

\footnotetext{
${ }^{6}$ Distopijska ne nužno u smislu upućivanja na neodgodivu 'propast' humanistike, već u smislu češćeg ukazivanja na trenutačne opasnosti koje, ako ih se previdi, mogu dovesti do njezine eventualne 'propasti'.
} 
različitim intelektualnim, emocionalnim i fizičkim iskustvima (Harari, Homo Deus: A Brief History of Tomorrow 193-94). Ta je nova formula znanja odredila i bit modernog humanističkog obrazovanja - naučiti studente da samostalno misle. Vrhovni izvor smisla i autoriteta premjestio se s nebesa (Bog) u ljudske osjećaje pa je tako najvažnija zadaća humanističkog obrazovanja osvijestiti što mi (čovjek) mislimo o stvarima. Vanjski je svemir postao prazan prostor, dok je unutarnji svijet čovjeka postao duboko i bogato mjesto (Harari, Homo Deus: A Brief History of Tomorrow 191).

Unatoč vrijednostima humanističkog obrazovanja i smislu koje su humanističke znanosti pružile novovjekovnom društvu, s vremenom, ali i razumljivim razvojem procesa koji je pokrenuo sam humanizam, došli smo do trenutka individualne i društvene krize humanističkih znanosti. Harari (21 Lessons for the 21st Century 209-14) vjeruje da spas humanističkih znanosti nije u akumuliranju više informacija i više znanja, već i dalje u otkrivanju smisla - u pronalasku smisla u moru podataka, informacija i znanja koje je pred nas stavila znanstveno-tehnološka revolucija. Jedan od najvećih izazova danas predstavlja oblikovanje kurikula i ishoda učenja jer nitko ne zna koji će poslovi biti traženi za 30-ak godina ni koje će vještine biti potrebne. Kritičko mišljenje, kreativnost, komunikacija i suradnja svakako su vještine koje će pomoći budućim generacijama, međutim mnogo važnije bit će vještine kako se nositi s promjenama, kako učiti nove stvari, kako iznova i iznova osmisliti sebe te kako zadržati mentalnu stabilnost i fleksibilnost i emocionalnu ravnotežu. U uvijek promjenjivoj tehnosferi najvažnije vještine koje moramo razviti jesu emocionalna inteligencija i mentalna stabilnost. Međutim, pitanje stabilnosti postaje problematično u društvu koje je mitologiziralo sve vanjske autoritete znanja i moći, od grčkih mislilaca, preko apsolutnog Boga, do matematike i humanističkog razuma, osjećaja, iskustva i slobodne volje. Zahvaljujući biotehnologiji, infotehnologiji i datafikaciji homo sapiens je postao hakabilna skupina biokemijskih podataka i algoritama. Osjećaji i iskustvo koji bi mu trebali pružiti odgovore postaju broj danih mogućnosti čija se izglednost može matematički izračunati na osnovu ulaznih podataka. Zahvaljujući algoritmizaciji, datafikaciji, praćenju i upravljanju pažnjom i drugim trendovima, tehnologija će nas uskoro poznati i razumjeti bolje od nas samih što predstavlja ugrozu humanističkom projektu slobodnog i racionalnog mišljenja i djelovanja ${ }^{7}$. Ako budemo htjeli sačuvati vlastitu autonomiju i slo-

\footnotetext{
7 Ta će ugroza obuhvatiti i humanističku obrazovnu praksu čiji je cilj (bio) objektivnost definicija zamijeniti subjektivnošću iskustva, odnosno „naučiti učenike/studente da misle za sebe“ jer „čovjek
} 
bodu, „upoznati samoga sebe“ postat će novi ključni projekt ljudskog društva. Stoga ono što sada preostaje, posebno u kontekstu vrijednosti koje proizlaze iz transhumanizma ${ }^{8}$ i prevladavajuće tehnoznanstvene logike, jest iskoristiti moć filozofije i disciplina humanističkih znanosti kako bismo ojačali i pripremili se za doba entropije i kaosa uzrokovane združivanjem biotehnologije i infotehnologije. Iako danas postoji neodoljiva želja za bavljenjem egzaktnim znanostima koje se oslanjaju na primjenu matematike, pa se tako i područja koja tradicionalno pripadaju humanističkim znanostima, poput lingvistike i psihologije, sve više oslanjanju na matematiku i statistiku, Harari smatra da će filozofija i humanističke znanosti postati važnijima nego ikad te da će transhumanističko i posthumanističko doba, čak možda i slučajno, dovesti do jednog novog humanizma i tako poduprijeti ljudsku potragu za razumom, slobodom i sviješću. U trenutku u kojem tehnologija pokušava hakirati ljudsku prirodu, jedno od glavnih pitanja bit će tko će prije i bolje upoznati čovjeka. Naspram visoko razvijene i sve sofisticiranije tehnologije, humanističke znanosti imaju možda 'sporije', ali mnogo moćnije i iskusnije oružje - filozofiju. Uz tzv. revitalizaciju filozofije, Harari predlaže još nekoliko strategija koje će čovjeku pomoći da povrati vjeru u samoga sebe: povratak osjećajima, iskustvu, slobodnoj volji, razumu i ponovnom preuzimanju odgovornosti; ${ }^{9}$ eliminiranje osjećaja beznačajnosti koji se nadvio nad postmodernim čovjekom; ${ }^{10}$ i zaustavljanje eksploatacije ljudske pažnje koja narušava mentalnu stabilnost nužnu za suočavanje s nedefiniranim i neodredivim realitetom.

U dokumentarnom filmu Never-Ending Man: Hayao Miyazaki Miyazaki, u razgovoru s razvojnim timom i animatorima jedne softverske tvrtke kojoj je cilj razviti umjetnu inteligenciju koja će, zahvaljujući konceptu dubokog učenja,

treba slušati sebe, svoje osjećaje i svoj razum“. Ako smo došli do točke u vremenu u kojemu algoritmi i društvene mreže znaju više o nama od nas samih dok mi sve više vremena posvećujemo, kako ističe Tristan Harris, usavršavanju strojeva (engl. upgrading machines) čime posljedično zapostavljamo čovjeka (engl. downgrading humans), koliko sigurni možemo biti da su naše odluke ispravnije od onih (naših) strojeva? Koliko možemo vjerovati našim osjećajima i našem razumu kada mnoštvo zainteresiranih strana nastoji hakirati našu pažnju i mišljenje? U takvom je okruženju sve teže vjerovati subjektivnom iskustvu i „misliti za sebe“.

${ }^{8}$ Mogućnosti hakiranja i promjene tijela, uma i kognitivnih sposobnosti potaknut će brojna filozofska pitanja i čovjeka suočiti s brojnim odlukama za što će mu biti potrebni duboko razumijevanje i uvidi u ljudsku prirodu i prirodu općenito.

${ }^{9}$ Jedan od razloga zašto su nam se algoritmi učinili tako privlačnima i zašto su tako lako preuzeli naš mikrokozmos jest taj što su nam ponudili oslobođenje od odgovornosti.

${ }^{10} \mathrm{Ne}$ samo u obliku etabliranja čovjeka kao beskorisne klase, već i kao vrste čiji su razum, osjećaji i iskustvo postali nepouzdani. 
„moći crtati i animirati poput ljudi”, kaže sljedeće: „Osjećam da se bliži kraj svijeta. Ljudi su izgubili povjerenje u sebe.“ Možda je Miyazaki u pravu, možda je problem u činjenici da su ljudi izgubili povjerenje u sebe i da su u tehnološki ovisnom društvu znanja zaboravili bit i primjenu tehnike. „Upravo je takvo, tehnoznanstveno, shvaćanje svijeta dovelo do zaborava biti i primjene tehnike umjesto u svrhu raskrinkavanja, sada u apsurdno ovladavanje samim sobom u svrhu razotkrivanja i preoblikovanja ljudske prirode“ (Selak 188).

Tijekom govora na promociji studenata 2005. godine autor David Foster Wallace zaključio je kako je jedan od ponavljajućih civilizacijskih problema taj što kao društvo često planiramo i gradimo 'sustave' na temelju najnižih aspekata ljudske prirode (poput pohlepe, sebičnosti, zavisti), a upravo one predstavljaju vrijednosti na kojima počivaju ekonomija 'niskog kapitalizma' i stalnog rasta, kultura neprestanog konzumerizma i društvo krajnje individualističke i utilitarističke orijentacije koji danas usmjeravaju većinu društvenih institucija i društvenog djelovanja. Transcendiranjem tih aspekata naše prirode kao i čvrsto ukorijenjenih vjerovanja organiziranih oko vrijednosti i zakona koji su tek dio povijesnog kontinuuma možemo steći uvid i kontekst nužne za razotkrivanje („raskrinkavanje“) složenosti realiteta i ljudske prirode. I tek će takvo kritičko i filozofski utemeljeno promišljanje razriješiti pitanja, prazninu i besmisao koje je stvorio redukcijski i mehanicistički pristup tehnoznanstvene logike. Tada će i 'sustavi' koje gradimo reflektirati činjenicu da je čovjek ponovno počeo vjerovati u sebe.

\section{3. (Postoji li) Budućnost humanistike iz transhumanističke perspektive?}

„Jim Hacker: Obrazovanje u ovoj zemlji je katastrofalno. Trebali bismo djecu pripremati za njihov radni vijek, a oni 3/4 vremena provedenog u školi umiru od dosade.

Humphrey Appleby: Ja bih pomislio da je 3/4 vremena provedenog umirući od dosade izvrsna priprema za radni vijek.“

(BBC serijal Da, premijeru)

Možda se iz trenutačne perspektive čini kao da je opstanak humanističkih znanosti ugrožen, barem u budućnosti kakvom ju zamišljaju i predviđaju transhumanisti i tehnofuturisti, te posebno ako se u obzir uzmu njihove kritike svega tradicionalnoga i svega onoga što se referira na povijest, odnosno njihovo in- 
zistiranje na stalnom poboljšanju i usavršavanju (ne samo 'manjkavog' čovjeka, već i svih institucija i procesa koje je on tako 'manjkav' stvorio). Tada se posve razumnim čini na takve kritike odgovoriti protunapadom, no obrana humanistike ne leži u napadanju Drukčijeg i Drugog ili u njezinu određenju kao posve različite od njih, jednako kao što ne leži u njezinu određenju isključivo kroz bavljenje rodnim studijama, feminističkom teorijom i pitanjem ljudskih prava, odnosno politikom identiteta. U tom smislu posthumanističke studije organizirane oko tih pitanja ne mogu biti jedini stup obrane humanističkih znanosti.

Iako predstavlja razuman pokušaj obnavljanja narušene humanističke homeostaze, metahumanistika kakvom ju vide del Val i Sorgner, ona u kojoj „meta“ podrazumijeva nadilaženje (engl. transcending) humanizma i humanistike, ponovno nas udaljava od izvornih humanističkih vrijednosti i ciljeva. Jedina metahumanistika koja bi imala smisla jest ona u kojoj „meta“ predstavlja sveobuhvatniji, širi, i svestraniji (engl. more comprehensive) pristup problematici krize $\mathrm{u}$ humanističkim znanostima. Primjerice, takav pristup u tzv. STEM revoluciji ne bi vidio isključivo destruktivan utjecaj tehnoznanosti, industrije, tržišta i tržišnih vrijednosti na obrazovanje (na kraju, u tom bismo smislu jednako mogli promatrati i moderni obrazovni sustav utemeljen na načelima industrijalizacije 19. stoljeća), nego i njezin konstruktivan pokušaj da kroz koncepte kao što su Do-It-Yourself (DIY) kultura, Maker pokret i peer learning vrati imaginaciju, inovaciju, kritičko mišljenje i kreativnost u obrazovni sustav koji se ponekad vrlo tromo postavlja spram sve dinamičnijeg i promjenjivijeg realiteta.

Po pitanju odnosa humanističkih i prirodnih i tehničkih znanosti, potrebno je izbjegavati čisto dualističko gledište, tj. polariziranje mišljenja. Stroga podjela na prirodne i humanističke znanosti ograničava mišljenje, refleksiju i imaginaciju potrebne za pravilno i sveobuhvatno razumijevanje krize humanistike. Činjenica da danas živimo u iznimno pluralističkom društvu još više otežava naum postizanja i zadržavanja konsenzusa. Lakše ga je, kako navodi ter Meulen, postići unutar manjih zajednica koje dijele zajedničke vrijednosti ili povezanost na osobnoj razini, pa se tako s lakoćom prihvaća ideja podjele, grupiranja, departmentalizacije i drugih oblika društvenog i institucionalnog 'raščlanjivanja' (69). No upravo taj trend neupitno podsjeća na načelo redukcionizma koje može vrlo disruptivno djelovati na strukturu organskog svijeta ili bilo kojeg drugog sustava. Slično tomu, brojne novostvorene znanstvene i obrazovne interesne zajednice koje se grupiraju oko zajedničkih načela i vrijednosti ili projektnih prijedloga počinju nalikovati interesnim zajednicama i tehnološkim plemenima 
proizašlima iz industrije Silicijske doline i internetske kulture, a koje je Nick Land kao nasljednik antidemokratske i antiegalitarističke reakcione filozofije Curtisa Yarvina najavio u svom manifestu The Dark Enligthenment 2012. godine (korporativna moć proizašla iz kapitalizma postat će organizirajuća sila u društvu koja će dovesti do formiranja interesnih zajednica). Te novostvorene zajednice i plemena kroz vlastite ideološke, znanstvene i druge okvire pokušavaju razumjeti i objasniti realitet s kojim se suočavaju uvijek iznova i iznova; jer nam realitet neprestano dolazi u 'novijoj, 'naprednijoj' i 'poboljšanoj' formi. Očuvanje jedinstvenosti, zajedništva, međusobnog razumijevanja i suradnje postalo je tako jedan od glavnih izazova znanstvenog i obrazovnog sustava, ali i glavni čimbenik njihova opstanka budući da je održavanje tih sustava sigurno koliko i budućnost svakog od njihovih elemenata.

Statistička izvješća Svjetskog ekonomskog foruma, rezultati istraživanja brojnih sveučilišta, agencija i zavoda, kao i sami pokazatelji koji dolaze od strane industrije i tržišta slažu se u tome da bi moderna znanost i obrazovanje trebali razvijati vještine poput kreativnosti, inovativnosti, prilagodljivosti, imaginacije, kreativnog mišljenja i dr. koje će studente uspješno pripremiti za promjenjivu i nestabilnu budućnost i akcelerirani tehnoznanstveni napredak. Mnoge od navedenih vještina pripadaju području upravo humanističkih znanosti. Međutim, citat s početka ulomka u sebi krije još jednu ključnu 'vještinu', onu koja je često tabu unutar diskursa ne samo o humanistici, nego i o obrazovanju općenito - kako prihvatiti dosadnu i neglamuroznu stranu posla koji će u određenim segmentima biti više ili manje repetitivan, nemaštovit i neizazovan zadržavši pritom motivaciju i uvid u smisao cijelog procesa? Kako zadržati koncentraciju, pomnost i predanost kada se put do cilja čini dalekim i napornim, a pritisak multitaskinga i borba za upravljanjem ljudskom pažnjom postaju sve izraženijima? Kako, u uvjetima stalne nesigurnosti, promjene i izazova, zadržati emocionalnu i mentalnu stabilnost nužnu za uspješno nošenje sa sve većom nepredvidivošću ne samo tržišta rada, nego i ljudskih odnosa i budućnosti općenito? Kako razvijati i njegovati svjesnost, suosjećanje i modus bivanja u kulturi koja inzistira na kompetitivnosti, individualizmu i konzumerizmu? Nisu li upravo to vještine i vrijednosti koje kao ključni aspekti ljudske prirode ne proizlaze iz inženjerskih i matematičkih zakonitosti i spoznaja, već iz izvornih humanističkih načela i vrijednosti? 


\section{Ontoepistemološke pretpostavke posthumanizma}

Posthumanizam označava termin koji se ponajviše veže uz redefiniranje pojma ljudskog, odnosno humanog u skladu s ontoepistemološkim, znanstvenim i biotehnološkim razvojem $s$ kraja dvadesetog i početka dvadeset i prvog stoljeća (Fernando 26). S obzirom na ontoepistemološki razvoj posthumanizam se najviše dovodi u vezu s postantropocentrizmom. Naime, kako se humanizam i prosvjetiteljstvo nikada nisu mogli svesti pod zajednički nazivnik, a za antropomorfizam i antropocentričnost humanizma istinsko prosvjetiteljstvo nikada nije imalo strpljenja (Foucault, What is Enlightenment? 47), današnje prosvjetiteljstvo (ili ono što je preostalo od njega) sve je više okrenuto onomu što je bilo izostavljeno iz antropocentričnog nazora. Zbog toga se na posthumanizam, u prvom redu, može gledati kao na pokušaj izmjene filozofskih stajališta u odnosu na pitanje što znači biti čovjekom u dobu postantropocentrizma, a tek nakon toga, i u kontekstu razvoja i obećanja novih tehnologija (Miah 20). Posthumanistička teorija tako smatra da nudi novu epistemologiju koja nije antropocentrična nastojeći potkopati uvriježene granice između onoga što nazivamo ljudskim, životinjskim i tehnološkim (Bolter 1). S druge strane, redefiniranje pojma ljudskog u okvirima razvoja humanističkih znanosti veže se uz nastanak posthumanistike.

Nekoliko knjiga koje su se pojavile sredinom ili u drugoj polovici 1990-ih direktno se vežu uz nastanak, odnosno pojavu posthumanizma. To su: The Posthuman Condition: Consciousness Beyond the Brain Roberta Pepperella, prvi put objavljena 1995; zatim, zbornik radova Posthumana tijela (Posthuman Bodies) pod uredništvom J. Halberstama i I. Irvingstona također objavljen iste godine; te knjiga Kako smo postali posthumani (How We Became Posthuman) Catherine N. Hayles prvi put objavljena 1999.

Između ostalog, posthumanizam se zalaže i za novu vrstu ljudi - tzv. postljude (engl. posthumans). U tom smislu, u literaturi se raspravlja o uvjetima nastajanja postljudi (engl. posthuman condition), a kada se govori o posthumanoj budućnosti (engl. posthuman future) zamišljaju se uglavnom dva scenarija: prema prvom, koji je zamislio Hugo de Garis, ljudi su u potpunosti nestali, te su na Zemlji preostali samo postljudi; prema drugom scenariju, koji pretpostavlja Kevin Warvick, ljudi i postljudi nastavit će supostojati, iako će potonji na koncu prevladati jer su, za razliku od ljudi, bili spremni pristati na medicinska poboljšanja (Anderson 209). 
Osim toga, važno je naglasiti i da posthumanizam ne predstavlja neku vrstu ne-humanizma. Ljudsko nije nestalo u posthumanizmu. Premda se ponekad protivi ljudskom te graniči s antihumanističkim nastojanjima, većina posthumanističkih teoretičara nema namjeru ljudsko proglasiti zastarjelim. Umjesto toga, postljudsko, koje se sada javlja u društvu, samo poziva na novu preraspodjelu razlika i identiteta u društvu (Halberstam i Livingstone 10). U tom smislu treba gledati na pojavu rodnih i feminističkih teorija koje prate odgovarajuće politike identiteta u suvremenom društvu. Prema tome, posthumanizam pretpostavlja humanizam, i kao što to akronim post-ističe, posthumanizam ne bi bio moguć bez humanizma.

Za razliku od humanizma, posthumanizam generira različite, pa čak i međusobno nepomirljive definicije (Wolfe xi) a što ima za posljedicu i razlikovanje više tipova, odnosno vrsta posthumanizma. Prema Fernando, razlikuju se tri vrste posthumanizma: kritički, kulturni i filozofski posthumanizam (27). Prema istoj autorici, kritički posthumanizam, koji se javlja sredinom 1990-ih u feminističkim studijama u okviru književne kritike (29), više je okrenut aktivističkom pristupu te pretpostavlja i politički angažman za rješavanje postavljenih pitanja u teorijskim radovima. Na primjer, zagovornici kritičkog posthumanizma gorljivo će se izjašnjavati za uporabu protetskih uređaja kao sredstava koja pomažu u svladavanju i nošenju s nekom bolešću, ali ne i za njihovu uporabu bez stvarne potrebe, primjerice, u kontekstu medicinskih poboljšanja ljudskih sposobnosti, a što zagovaraju transhumanistički mislioci. Tako su i obećanja koja nudi razvoj tehnologije tim teoretičarima manje važna. U autore kritičkog posthumanizma mogu se svrstati Anne Balsamo, Rosi Braidotti i drugi autori.

U isto vrijeme kada nastaje i kritički posthumanizam, iz velikog broja različitih kulturalnih studija proizlazi i razvoj kulturalnog posthumanizma (Miah 6). Teoretičari posthumanizma, Andy Miah (6) i Francesca Fernando (29) slažu se da on započinje zbornikom radova naziva Posthumana tijela koji su uredile Judith M. Halberstam i Ira Livingstone, koji je objavljen 1995. U uvodniku zbornika, urednice ističu da posthumana tijela nastaju kao posljedice postmodernih odnosa „...moći i užitka, virtualnosti i stvarnosti, uključujući i sve njihove konsekvence" (Halberstam i Livingstone 3). Katherine N. Hayles, Neil Badmington i Elaine Graham samo su neka od imena teoretičara kulturnog posthumanizma. Tako, primjerice, Katherine N. Hayles u svojoj knjizi Kako smo postali posthumani razmatra mogućnost ideje 'pohranjivanja uma' (engl. mind uploading) u računalo koju je prvi iznio Hans Moravec. Ne razmatrajući tehničke aspekte te 
ideje koja predviđa transformiranje ljudskog tijela u informacije, Hayles primjećuje da Moravec, zapravo, ne napušta humanizam, nego moć liberalnog humanističkog subjekta širi u područja posthumanog (287).

Tek početkom 2000-ih ta dva smjera konvergiraju u jedan, otada fokusiran isključivo na filozofska promišljanja. Tako se filozofski posthumanizam bavi moralnim i etičkim pitanjima, ali u postantropocentričnom smislu, što uključuje rasprave o pravima ne-bioloških entiteta poput strojeva umjetne inteligencije, životinjskoj etici (engl. animal ethics), kućnim ljubimcima kao pridruženim vrstama ljudskoj vrsti (Haraway 2) i sl. U trenutku kada je tehnocentričnost zamijenila antropocentričnost, pozicija čovjeka kao tzv. ljudske životinje (engl. human animal) počela se približavati poziciji životinja, pa i biljaka. Čovjek sve manje ima ulogu kontrolora i upravitelja ekosustava čije se odluke temelje ponajprije na dobrobiti 'ljudskih životinja', a sve više u obzir uzima posljedice vlastita djelovanja na ostale njegove elemente te promišlja vlastitu vrstu u odnosu na druge vrste.

Sve u svemu, stječe se dojam da se u raspravama o posthumanizmu javljaju najmanje četiri struje mišljenja ili diskursa koje se međusobno razlikuju prema stavu spram posthumanističkih vizija budućnosti čovječanstva; to su biokonzervativistička, pesimistična, optimistična te antihumanistička struja. I Tamar Sharon u svojoj knjizi Ljudska priroda u doba biotehnologije (Human Nature in an Age of Biotechnology) također razlikuje četiri vrste posthumanističkog diskursa: distopijski, liberalni, radikalni i metodološki, za koje se čini da su u analogiji s predloženim razlikovanjem u ovom radu (Sharon 5).

Biokonzervativistička struja mišljenja na posthumanizam gleda kao na negativnu pojavu, u posthumanističkim idejama vidi opasnost za čovječanstvo izlažući ga zbog toga konstantnoj kritici. U svojoj knjizi Naša posthumana budućnost (Our Posthuman Future) iz 2002. Francis Fukuyama zabrinuto iznosi tvrdnju prema kojoj posthumanisti žele današnje čovječanstvo zamijeniti novom vrstom (engl. species). Transhumanističku ideju i doslovno naziva trenutačno „najopasnijom na svijetu“ jer u nemoralnosti medicinskih poboljšanja, odnosno ljudskog unaprjeđenja putem tehnologije i političkim grupacijama koje će ih zagovarati vidi najveći izvor problema (Fukuyama 7). I Braidotti primjećuje da teoretičari različitih političkih pozadina, poput Habermasa, Fukuyame, Sloterdijka, pa čak i jednog Derridaee, izražavaju snažnu tjeskobu koja graniči s moralnom panikom o budućnosti ljudske i humanističke baštine u vremenu 
ubrzanog tehnološkog razvoja (A Theoretical Framework for the Critical Posthumanities 35). ${ }^{11}$

Pesimistična struja mišljenja, pak, izglede čovječanstva u posthumanom dobu vidi u najrazličitijim distopijskim scenarijima: od mogućnosti potpunog izumiranja (Moynihan) do rata između ljudi i strojeva umjetne inteligencije, a koji bi mogao dovesti i do istrebljenja čovječanstva kao vrste (Hugo de Garis). Do čega pesimistične posthumanističke ideje mogu na koncu dovesti najbolje pokazuje primjer inicijative Dobrovoljnog pokreta za ljudsko izumiranje ( Voluntary Human Extinction Movement) čiji je cilj i doslovno dovesti do dobrovoljnog, stupnjevitog izumiranja čovječanstva kao vrste na planetu. Kao svoju konkretnu akciju, inicijativa ističe poziv na trenutačno zaustavljanje ljudske reprodukcije, jer čovječanstvo više nije u stanju živjeti održivim načinom života te svojim postojanjem šteti svojoj okolini, planetu Zemlji.

U optimističnu struju mišljenja u posthumanizmu, uz transhumanističke teoretičare i praktičare, poput Donne Haraway, Nicka Bostroma, Raya Kurzweila, Hansa Moraveca i dr. pripadaju i izrazito posthumanistički mislioci poput Roberta Pepperela, Neila Badmingtona, Elaine Graham i drugih. Prema Pepperellu, potrebno je prihvatiti da „ljudi nisu više najvažnije stvari u svemiru“ (177). Najprije smo razlikovali Boga, Čovjeka i Prirodu; zatim su racionalisti - utjelovljeni prosvjetiteljskim misliocima kao što su Voltaire, Rousseau i Kant - raskrstili s Bogom, ostavivši Čovjeka u vječnom sukobu s Prirodom. Danas, posthumanisti iz toga odnosa brišu Čovjeka, ostavljajući na povijesnoj pozornici samo Prirodu. Međutim, „razlike između Boga, prirode i čovječanstva ne predstavljaju nikakvu vječnu istinu o ljudskom stanju“ (Pepperell 178-79). Mi, zapravo, nikada nećemo saznati kako Priroda, odnosno svemir funkcioniraju. „Znanost nikada neće postići svoj cilj razumijevanja konačne prirode stvarnosti.“ Znanje je uvjetovano podacima, a podaci se međusobno razlikuju u razlučivosti. Pojava reda i nereda u našim istraživanjima zbilje više govori o tomu na koji načinu obrađujemo informacije, nego o prisutnosti stvarnog reda ili nereda u prirodi (Pepperell 179-80).

\footnotetext{
${ }^{11}$ Biokonzervativistički duh i općenito sumnju u budućnost čovječanstva potpomognutu razvojem tehnologije možda najbolje dočarava scena nakon završetka šahovskog meča između svjetskog prvaka u šahu Garija Kasparova i IBM-ova stroja Deep Bluea 1997. u kojem je na kraju premoćnu pobjedu ostvarilo IBM-ovo računalo. Imajući mogućnost pozdraviti sudionike na pozornici nakon šahovskog meča, publika je izrazila vidno razočarenje njegovim ishodom zaboravivši čestitati na pobjedi IBM-ovim programerima.
} 
I konačno, antihumanističku struju obilježava potpuna dekonstrukcija pojma ljudskog u svom narativu (Ferrando 31). Možda ju se i ne može smatrati posthumanističkom idejom u pravom smislu te riječi, nego samo pokretom koji u postmodernom dobu ima zajedničke korijene s posthumanizmom. Pojam antihumanizma mnogi će dovesti u vezu s maksimom Michela Foucaulta o smrti čovjeka (engl. death of Man) (387). Za Johna Cairesa ljudi su postali vrsta izvan kontrole (1), a za Franka Furedija sama znanost i znanje pomažu intenziviranju destruktivnog kapaciteta ljudske vrste te je, na neki način, sâm humanizam postao problem (Furedi 24). S druge strane, Nick Land, „otac“ ideje akceleracionizma, a po nekima i Nietzsche našeg doba (Fisher 341) uvjerenja je da više ne stoji do čovjeka da razmišlja o tehnici, prema filozofskoj zaostavštini Martina Heideggera, jer je, u međuvremenu, sama tehnika započela razmišljati o sebi. Moglo bi proći tek nekoliko desetljeća prije nego što umjetna inteligencija nadiđe horizont biološke inteligencije. Zbog toga je krajnje neutemeljeno zamišljati da će ljudska vlast nad zemaljskim dobrima trajati stoljećima. Za Landa se visoko mišljenje više ne treba baviti produbljivanjem ljudske spoznaje, jer će uskoro sama spoznaja postati neljudska, i to nakon što migrira $u$,dehumanizirane krajolike“ i od humanog ,ispražnjene prostore“ (Deleuze 5), a u kojima će se ljudska kultura, na koncu, istopiti (Land 293). Prema Landu, prirodne znanosti su danas „ekskluzivni kapitalistički fenomen“ (48). Čak i filozofiju jednog Kanta on tumači kao „...vrstu nesvjesne dramatizacije sučeljavanja između socijalnog konzervativizma i nagrizajućih moći Kapitala“ (MacKay 266). Svojim, često kontroverznim idejama, čini se da je umnogome doprinio stavu prema kojemu se umjetna inteligencija smatra dominantnijom u odnosu na ljudsku, zbog čega će se čovječanstvo jednoga dana morati suočiti s mogućnošću vlastitog izumiranja.

Premda posthumanizam neprijeporno upućuje i na rasprave o konsekvencama transformacije čovječanstva pod utjecajem razvoja tehnologije, ta se tema u literaturi više veže uz transhumanizam. Tako je većina posthumanističkih teoretičara više okrenuta transformacijama čovječanstva pod utjecajem postantropocentrizma i postprosvjetiteljskog şkepticizma uzrokovanog otkrićem pristranosti humanističkog subjekta u svojim sudovima o samome sebi, primjerice, $\mathrm{u}$ odbacivanju životinjskog podrijetla. No, nikada ne smijemo smetnuti s uma da je ‘čovjek postao čovjekom' ne samo potiskivanjem svog životinjskog podrijetla u prirodi, nego i zbog sposobnosti da nadiđe veze s materijalnošću i vlastitom tjelesnošću. Tako se u posthumanizmu nikada ne radi o odbacivanju humaniz- 
ma po kratkom postupku, jer upravo u humanizmu postoje mnoge vrijednosti i opredjeljenja kojima se treba diviti - nego u pokazivanju kako su oni potkopani upravo onim istim filozofskim i etičkim načelima koji su prokrčili put prosvjetiteljstvu, te se koristili za njegovu konceptualizaciju (Wolfe xvi). „Prosvjetiteljska racionalnost kao da nije bila dovoljno racionalna jer je vlastite protokole i opredijeljenost prestajala primjenjivati kada se radilo o njoj samoj“ (Wolfe xx).

\section{Prema posthumanistici}

Sa znanstvenog stajališta, posthumanistički teoretičari predlažu potpunu rekonfiguraciju humanističkih znanosti koja bi trebala dovesti do toga da se „liberalni subjekt“ ukloni iz središta humanističkih istraživanja (Bolter 7). I prema Braidotti, humanistika mora mutirati i postati posthumanistika, ako ne želi ostati nevažna (The Posthuman 147). No, humanistika je kao takva oduvijek ignorirala pitanje mogućnosti neljudske subjektivnosti što je i razumljivo s obzirom na to da u centru svog proučavanja ima čovjeka. Možda i najeklatantniji primjer neljudske subjektivnosti koju nudi posthumanistička perspektiva predstavlja kiborg, koji se nalazi u fokusu istraživanja Donne Haraway, ključne figure u istraživanju porozne granice kontinuuma između ljudskog, životinjskog i strojnog (Bolter 2). Jonathan Culler čini početni korak prema odgovoru na ta pitanja. „Možda bi“, piše on, „koristan pristup krizi humanističkih znanosti bio pokušati izmisliti novo ime kako naše discipline ne bi obilježilo ime koje u sebi nosi potencijalno zabludu u ideologiji“ (42). Kako Culler nije ponudi 'novo ime', Neil Badmington predlaže da to bude posthumanistika (266). Prema Badmingtonu, posthumanizam nikada nije ono što jednostavno slijedi - kronološki, apokaliptično - nakon humanizma. Međutim, mogućnost postojanja i proučavanja neljudske subjektivnosti - nešto je što nužno inicira dolazak posthumanistike. U skladu s navedenim, termin „novi humanizam“ koji je predložio Derrida u svojim kasnim radovima, i koji bi istraživao „što je čovjeku primjereno" Badmington predlaže da se zamijeni terminom posthumanizam (266-67).

Kada se govori o razvoju posthumanistike, nije moguće zaobići posthumanističku etiku Rosi Braidotti. Prema Braidotti, kritička posthumanistika (engl. critical posthumanities) predstavlja novo polje istraživanja utemeljeno na konvergenciji posthumanizma i postantropocentrizma. Konceptualno uporište za posthumanistiku autorica vidi u neospinozističkoj monističkoj ontologiji koja pretpostavlja primat inteligentne i samoorganizirajuće materije (A Theoretical Framework for the Critical Posthumanities 31). Kritička posthumanistika pred- 
stavlja interdisciplinarno područje usmjereno na nove diskurse u području nehumanog, transhumanog, metahumanog i posthumanog, odnosno na različite percepcije fenomena 'humanog' u posthumanom dobu. Njezin cilj nije postići konsenzus po pitanju određenja i značenja 'humanog, već „ponuditi određeni okvir za aktualizaciju svih 'nestalih osoba' čija znanja i uvidi mogu biti poticaj novim oblicima budućnosti“. Općenito govoreći, konsenzus je teško postići jer se gotovo svaki fenomen posthumanog doba (bila to moć, vrijeme, čovjek ili nešto drugo) može opisati kao višeslojni, višedimenzionalni i višesmjerni (Braidotti 53). Kritička posthumanistika na neki način daje odgovor na pitanje što humanističke znanosti mogu postati u posthumanističko doba. S druge strane, jasno je da je kritička posthumanistika zahvaćena ubrzanom vrtnjom neoliberalne logike kapitalizacije samog života. Razvija se brže nego što akademske institucije mogu držati korak između sveučilišta, društvenih pokreta i korporativnih interesa ( $A$ Theoretical Framework for the Critical Posthumanities 47). Najveća smetnja ili prepreka u posthumanom dobu jest oportunistička komodifikacija svog živog svijeta, a koja je posljedica širenja političke ekonomije naprednog kapitalizma (Braidotti 34). „Svjedočimo usmjeravanju ka biznisu, menadžmentu i STEM predmetima, te udaljavanju od humanistike..." (Hall 33). Tom svojevrsnom obliku disrupcije humanistike (Hibert 99), koji se ogleda u poniznom stavu umjetnosti i humanistike prema prirodnim znanostima i industriji, također mora doći kraj (Lovink 22-23). No, s obzirom na navedeno, opoziciju kritičkoj posthumanistici, prema Braidotti, predstavlja upravo transhumanizam koji postljude definira kao 'super-ljude', svojevrsna metaracionalistička stvorenja. Za autoricu, Nick Bostrom šampion je Capitaloscena koji podjednako privlači pozornost „kraljevske“ znanstvene zajednice i korporacijskih tvrtki. Ono što Braidotti predlaže je alternativa tom pristupu, naime: 'sporedna znanost' i nomadska kritička posthumanistika (A Theoretical Framework for the Critical Posthumanities 48).

Na kraju ovog poglavlja, kao primjer napora na utemeljenju nove discipline koja bi nosila naziv posthumanistika, može se spomenuti Posthumanistički hub pokrenut 2008. koji predstavlja portal za posthumanistiku ili, kako to sami autori napominju - humanistiku koja pruža više od postojeće humanistike (engl. more-than-human humanities), odnosno humanističkih znanosti (The Posthumanities $H u b$ ). Na posthumanističkom hubu raspravlja se o temama poput humanistike okoliša (engl. environmental humanities), humanih životinjskih studija (engl. human animal studies), digitalne i tehnohumanistike (engl. digital and techno-humanities) itd. (The Posthumanities Hub). 


\section{Zaključak}

Unatoč a priori bezizlaznosti situacije, posthumanistika, ultrahumanistika i metahumanistika kao oblici koji će retradicionalizirati i rekonstitualizirati načela i vrijednosti humanistike nude mogućnost ne samo za 'opstanak' humanističkih znanosti kao autonomnih i nužnih, već i za sinergiju humanističkih znanosti i trendova i vrijednosti koje donose trans- i posthumanizam. Ta sinergija predmnijeva više 'zaključaka'. Filozofska refleksija i kritičko pozicioniranje nužni su za uspješno suočavanje s promjenjivim realitetom. Da bi se reducirala pretjerana objektivizacija znanosti i obrazovanja potrebno je vratiti odgovornost subjektu i povjerenje u subjekt. De(kon)strukcija obrazovanja i znanosti nije samo posljedica rođenja tehnosfere kao tehnološke i znanstvene (materijalne) strukture, nego i posljedica rođenja nove ideološke strukture nastale opunomoćivanjem eksponencijalnog ekonomskog rasta, tržišnih zakona i profita, utilitarizma i pragmatizma te birokratizacije i antitradicionalnosti kao općih društvenih standarda i smjernica. Potrebno je mobilizirati otpor ne kroz diskurs odbacivanja, vrijeđanja ili marginaliziranja, već kroz egzemplarno djelovanje. Dijalog, otvorenost, razumijevanje i suradnja mogu osloboditi humanističke znanosti stigme tromosti, zatvorenosti, beskorisnosti i drugih epiteta koji zatomljuju njihovu stvarnu društvenu ulogu i značaj. Nužno je izaći iz sjene nepovjerenja prema Drugom i Drukčijem jer kriza humanistike nije sadržana isključivo u refleksiji znanstvenog i tehnološkog napretka, nego i u refleksiji nedostatka introspekcije, autorefleksije $i$ doživljavanja alteriteta kao nama ravnopravnog i slobodnog da u različitosti od nas pronalazi svoj smisao i cilj. Potrebno je pomiriti ciljeve humanističkog i neoliberalnog obrazovanja jer u trenutku kada tržište rada svojom dinamikom, fleksibilnošću i akceleracijom kreira zamor, dosadu i prazninu u subjektu, jedini pokušaj nadilaženja takve egzistencije jesu (samo)svijest, (samo)spoznaja, kontemplacija, usredotočenost, kognitivno sazrijevanje, mentalna stabilnost i slobodno umno djelovanje - sposobnosti i vještine kojima nas može poučiti samo humanističko obrazovanje. Sveučilišta moraju svjesno upravljati načelima performativnosti, pragmatičnosti, administrativne prikladnosti i logičnosti u instrumentalnom smislu jer to nisu jedina načela koja opravdavaju epitet znanstvenosti. I zaključno, možda i najvažnije, humanističko obrazovanje ne trebamo promatrati kao ono koje je tu unatoč širim paradigmatskim i ideološkim promjenama, već kao ono koje je tu upravo zbog tih promjena. 


\section{Literatura}

Anderson, Janna Quitney. Imagining the Internet: Personalities, Predictions, Perspectives. Rowman \& Littlefield Publishers, 2005.

Badmington, Neil. „Cultural Studies and the Posthumanities.“ New Cultural Studies: Adventures in Theory, uredili Cary Hall i Claire Birchall, 2006, str. 260-72.

---. urednik. Posthumanism. Palgrave, 2000.

Benedikter, Roland i Katja Siepmann. „Transhumanism“: A New Global Political Trend.” Challenge, sv. 0, br. 0, 2016, str. 1-13.

Bolecki, Wlodzimierz. „A Different Take on Humanities.“ The Humanities and Posthumanism, uredio Grzegorz Grochowski. Publishing House of the Institute of Literary Research, Polish Academy of Science, 2015, str. 46-52.

Bolter, Jay David. „Posthumanism.“ The International Encyclopedia of Communication Theory and Philosophy, uredio Jensen, Klaus Bruhn Jensen i Robert T. Craig, 2016, str. 1-8.

Bostrom, Nick. „A History of Transhumanist Thought“. Journal of Evolution and Technology, sv. 14, br. 1, 2005, https://jetpress.org/volume14/bostrom.html. Pristupljeno 20. srpnja 2020.

Braidotti, Rosi. „A Theoretical Framework for the Critical Posthumanities.“ Theory, Culture \& Society, sv. 36, br. 6, 2019, str. 31-61.

---. The Posthuman. John Wiley \& Sons, 2013.

Cairns, John. „Transitions: Speculative Futures for Homo sapiens.“ Science and Society, sv. 3, br. 2, 2005, str. 5-10.

Culler, Jonathan. „In Need of a Name? A Response to Geoffrey Harpham.“ New Literary History, sv. 36, br. 1, 2005, str. 37-42.

Deleuze, Gilles. Cinema 2: The Time Image. U of Minnesota P, 1989.

Ferrando, Francesca. „Posthumanism, Transhumanism, Antihumanism, Metahumanism, and New Materialisms.“ Existenz, sv. 8, br. 2, 2013, str. 26-32.

Fisher, Mark. „Terminator vs. Avatar: Notes on Accelerationism.“ Accelerate: The Accelerationist Reader, 2010, str. 335-46.

Foucault, Michel. What is Enlightenment? The Foucault Reader, edited by Paul Rabinow, translated by Catherine Porter, Pantheon, 1984), 32-50. str. 32-50.

---. The Order of Things: An Archaeology of the Human Sciences. Preveo Alan Sheridan-Smith, Pantheon, 1971.

Fukuyama, Francis. Our Posthuman Future: Consequences of the Biotechnology Revolution. Farrar, Straus and Giroux, 2003.

Furedi, Frank. „The Legacy of Humanism. “ Debating Humanism, uredio Dolan Cummings, Imprint Academic, 2006, str. 22-29.

Gibson, Poppy Frances. „From Humanities to Metahumanities: Transhumanism and the Future of Education." Compass: Journal of Learning and Teaching, sv. 11, br. 2, 2018, https://journals.gre.ac.uk/index.php/compass/issue/view/70. Pristupljeno 2. kolovoza 2020. 
Halberstam, Judith i Ira Livingston, urednici. Posthuman Bodies. Indiana UP, 1995.

Hall, Gary. The Uberfication of the University. U of Minnesota P, 2016.

Harari, Yuval Noah. 21 Lessons for the 21st Century. Jonathan Cape, 2018.

---. Homo Deus: A Brief History of Tomorrow. Harper, 2016.

---. Sapiens: A Brief History of Human Kind. Signal Books, 2014.

Haraway, Donna. The Companion Species Manifesto. Prickly Paradigm Press, 2006.

Hayles, N. Katherine. How We Became Posthuman: Virtual Bodies in Cybernetics, Literature, and Informatics. U of Chicago P, 1999.

Hibert, Mario. Digitalni odrast i postdigitalna dobra: kritičko bibliotekarstvo, disruptivni mediji i taktičko obrazovanje. Multimedijalni institut, Institut za političku ekologiju, 2018.

Hughes, James. „Contradictions from the Enightenment Roots of Transhumanism. “Journal of Medicine and Philosophy, sv. 35, br. 6, 2010, str. 622-40.

Jotterand, Fabrice. „At the Roots of Transhumanism: From the Enlightenment to a Post-Human Future." Journal of Medicine and Philosophy, sv. 35, br. 6, 2010, str. 617-21.

Land, Nick. „Circuitries.“ Pli: Warwick Journal of Philosophy, sv. 4, br. 1-2, 1992, str. 217-35.

---. Fanged Noumena: Collected Writings 1987-2007. Urbanomic/Sequence Press, 2018.

Lovink, Geert. Social Media Abyss: Critical Internet Cultures and the Force of Negation. John Wiley \& Sons, 2017.

Lyotard, Jean-Francois. Postmoderno stanje: Izvještaj o znanju. Prevela Tatiana Tadić, Ibis grafika d.o.o., 2005.

Mackay, Robin. „Nick Land-An Experiment in Inhumanism.“ A Nick Land Reader Selected Writings, 2017, str. 264-74.

Marcelić, Sven. „Suvremeni modeli sveučilišta i njihova kritika u društvenim znanostima.“ Socijalna ekologija: časopis za ekološku misao i sociologijska istraživanja okoline, sv. 24, br. 1, 2015, str. 41-62.

Markowski, Micahel Pawel. „Humanities: an Unfinished Project.“ The Humanities and Posthumanism, uredio Grzegorz Grochowski, Publishing House of the Institute of Literary Research, Polish Academy of Science, 2015, str. 13-28.

ter Meulen, Ruud. „Dignity, Posthumanism, and the Community of values.“ The American Journal of Bioethics, sv.10, br. 7, 2010, str. 69-70.

Miah, Andy. „A Critical History of Posthumanism. "Medical Enhancement and Posthumanity, uredili Bert Gordijn i Ruth Chadwick, Springer Science \& Business Media, 2008, str. 71-94.

Moynihan, Thomas. The Intellectual Discovery of Human Extinction. Diss. University of Oxford, 2019.

Nussbaum, Martha C. Ne profitu: zato demokracija treba humanistiku. Preveo Nebojša Mudri, AGM, 2012.

Paić, Žarko. „Pitanje o prosvjetiteljstvu: Foucault i kritika modernosti.“ Studia lexicographica: časopis za leksikografiju i enciklopedistiku, sv. 7, br. 2, 2013, str. 181-211. 
---. Posthumano stanje: Kraj čovjeka i mogućnosti druge povijesti. Litteris, 2011.

Pepperell, Robert. The Posthuman Condition: Consciousness Beyond the Brain. Intellect, 2003.

Selak, Marija. Ljudska priroda i nova epoha. Naklada Breza, 2013.

Sharon, Tamar. Human Nature in an Age of Biotechnology: The Case for Mediated Posthumanism. Springer, 2014.

The Posthumanities Hub. European Research Council, et al, 2008, https://posthumanities. net/. Pristupljeno 1. rujna 2020.

del Val, Jaime. „Multiversal Declaration of Metahuman Rights.“ METABODY, https://metabody.eu/wp-content/uploads/2020/07/MULTIVERSAL-DECLARATION-OF-METAHUMAN-RIGHTS-1.pdf. Pristupljeno 15. kolovoza 2020.

del Val, Jaime i Sorgner, Stefan Lorenz. „A Metahumanist Manifesto.“ Nietzsche Circle: A Philosophical Community, http://www.nietzschecircle.com/AGONIST/2011_08/ METAHUMAN_MANIFESTO.html. Pristupljeno 15. kolovoza 2020.

Wolfe, Cary. What is Posthumanism? sv. 8, U of Minnesota P, 2010. 


\title{
THE HUMANITIES FROM THE PERSPECTIVE OF TRANSHUMANISM AND POSTHUMANISM
}

\author{
Abstract \\ Milijana MIČUNOVIĆ \\ Josip Juraj Strossmayer University of Osijek \\ Faculty of Humanities and Social Sciences \\ Lorenza Jägera 9 \\ HR - 31000 Osijek \\ mmicunov@ffos.hr \\ Boris BOSANČIĆ \\ Josip Juraj Strossmayer University of Osijek \\ Faculty of Humanities and Social Sciences \\ Lorenza Jägera 9 \\ HR - 31000 Osijek \\ bbosancic@ffos.hr
}

Transhumanism is an intellectual, cultural, scientific, and artistic movement based on the convergence of science, technology, and economy. It supports the growth and application of new scientific and technological solutions in enhancing physical, mental, and other human abilities. On the other hand, posthumanism is a term (or a school of thought) that mostly refers to the redefining of the concept of human(e) in terms of the onto-epistemological, scientific, and biotechnological progress at the end of the twentieth and the beginning of the twenty-first century. Inevitably overlapping, these two movements or schools of thought imminently influence the evolution of the humanities, which are currently experiencing the so-called silent crisis. This crisis manifests in neglecting not only arts and humanities, but also the process of imagination, creativity, and critical thinking in every scientific area. The future of the humanities from the perspective of transhumanism and its value system implies two possible insights. The first refers to the issue of the humanities' positioning, that is, their relationship towards natural and technical sciences. The other points out the issue of values and skills that the humanities should promote, especially regarding the challenges of the scientific and technological revolution. From the perspective of the posthumanities comes an idea of a complete reconfiguration of the humanities that would replace man as a central figure of humanities' research. Thus, if the humanities wish to stay relevant and participated in the latest developments, they must morph into posthumanities, ultra-humanities, and 
metahumanities. Accordingly, critical posthumanities represent an interdisciplinary field focused on new discourse in the area of nonhuman, transhuman, metahuman, and posthuman, that is, a field focused on different perceptions of the concept of "human," and thus the perception of the humanities in the posthuman age.

Keywords: humanities, transhumanism, posthumanism, posthumanities 